\title{
The Immigrant as "the Other". Towards Differential Cultural Models
}

\author{
Adam Glaz \\ Uniwersytet Marii Curie-Skłodowskiej w Lublinie \\ adam.glaz@umcs.pll
}

\begin{abstract}
The study looks at how the notion of the Other, understood here as an ethnically, religiously, linguistically, and/or racially "different" immigrant, is portrayed in a specific section of English-language media discourse. The data come from British, American, Canadian, Australian, and New Zealand media (predominantly the press) but are limited to six articles in total, so that the proposed analysis is qualitative, rather than quantitative or statistical. It is an exercise in reconstructing a cultural model of the Other, not a presentation of a finished product, which - if and when the analysis is expanded to cover a much more extensive corpus - can yield descriptions of this heterogeneous notion in terms of differential cultural models. On the theoretical side, the study also links cultural model to the notion of cultural mindset.
\end{abstract}

Keywords: the Other, cultural model, cultural mindset, immigrant, media discourse

Streszczenie

Imigrant jako „Inny”. W stronę różnych modeli kulturowych

$W$ artykule rozważa się, $w$ jaki sposób pojęcie Innego, rozumianego tu jako imigranta różniącego się od mieszkańców kraju, do którego przybywa pod względem etnicznym, religijnym, jezykowym i rasowym, przedstawiane jest $w$ wybranym segmencie anglojęzycznego dyskursu medialnego. Dane pochodza z mediów brytyjskich, amerykańskich, kanadyjskich, australijskich i nowozelandzkich (głównie z prasy), lecz ponieważ sa ograniczone do sześciu wybranych artykutów, proponowana analiza ma charakter jakościowy, nie ilościowy czy statystyczny. Jest to zatem propozycja metody rekonstrukcji modelu kulturowego (cultural model) danego pojęcia, nie zaś prezentacja skończonego modelu (w tym wypadku Innego). Przy zastosowaniu tej metody, ilościowe i jakościowe poszerzenie korpusu poddawanego analizie może pomóc $w$ stworzeniu opisów różnych modeli kulturowych heterogenicznego pojęcia Innego. Pod względem teoretycznym pojęcie modelu kulturowego wiąze się także w niniejszej pracy z pojęciem kulturowej ramy mentalnej (cultural mindset).

Stowa kluczowe: Inny, model kulturowy, kulturowa rama mentalna, imigranci, dyskurs medialny 


\section{The key notions}

The present study is to be taken as a contribution to a broader endeavour of delineating differential cultural models of "the Other", as they transpire through media discourse. In the current socio-political climate that is largely hostile to otherness, it becomes increasingly difficult to bring various portrayals of the Other to a common denominator. Therefore, it is no accident that in their wide-ranging project, Chovanec and Molek-Kozakowska (2017) talk about the Other in media "discourses" (plural), whose varied national, political, and ideological profiles demand both careful attention to detail and informed synthetic judgement. This study is much narrower in its focus and scope, although it draws from geographically more diverse data, whose selection is explained below.

The notion of the Other is pregnant with psychological, social, and phenomenological content, and has been a subject of serious philosophical debate at least since Georg Hegel's (1807) idea of the Self as being consciously accessible and definable through is counterpart Other. That contrast became more nebulous when Edmund Husserl (1931) proposed to view the Other as an alter ego of the Self, a mere perception of the Self's consciousness. Thus, rather than dealing with a clearly defined subject Self and a clearly defined object Other, we are faced with an intersubjective relation between the two. These ideas were then elaborated on phenomenological grounds by Jean-Paul Sartre (1943), on psychoanalytic grounds by Jacques Lacan (1997/1981), and on ethical grounds by Emmanuel Lévinas (1961, 1974), the latter author being a major source of inspiration for the Polish journalist and writer Ryszard Kapuściński. Kapuściński is invoked here for a reason: his work as a journalist and reporter approximates the media context but at the same time draws from philosophical, humanistic, and personalistic considerations.

In most (if not all) of his writings, Kapuściński is concerned with a quest for understanding the Other in a sense derived from but narrower than Lévinas's: he uses the notion "to distinguish Europeans, people from the West, whites, from [...] non-Europeans, non-whites, while fully aware that for the latter, the former are just as much 'Others" (Kapuściński 2009: 13) ${ }^{1}$. Inspired by this understanding, the analysis proposed below is concerned with the Other as the immigrant. Specifically, an attempt will be made to reconstruct a certain variant or profile of the immigrant, when that immigrant, viewed from the perspective of English-speaking inhabitants of Western countries, is racially, ethnically, religiously, and linguistically "different". Importantly, "Western" here is to be understood in a 
cultural rather than a geographical sense, as the data for analysis come from British, US, Canadian, Australian, and New Zealand media (mainly the press).

The profile of the immigrant thus delimited can hopefully be captured in terms of a cultural model. A cultural model (or a cognitive-cultural model, cf. e.g. Kristiansen and Dirven 2008: 9), has enjoyed a long tradition of research ${ }^{2}$ that has been geared towards an account of what it means for culture to be, on the one hand, "individually rooted", but on the other, "collectively shared" (Bennardo and De Munck 2014: 281). These considerations have led to the emergence of the notion of distributed cultural cognition or simply cultural cognition, whose distributed nature is taken as understood (see e.g. D’Andrade 1989, Hutchins 1995, Sharifian 2017a, or Kronenfeld 2018). The present study is an attempt to contribute to an understanding and account of cultural conceptualisations (of the Other) in terms of cultural models.

When Bennardo and De Munck define cultural models as "mental representations shared by members of a culture" (2014: 3 ), they are aware that their definition is clear enough to be attractive and yet general enough to spark a discussion. They explain their views on how mental representations can be shared rather than individual, what culture means, how cultural models originate, how people experience them, and what those models tell us about the people and the world they inhabit. The definition of a cultural model proposed here is largely consistent with Bennardo and De Munck's, and in fact consistent with what can generally be found in the literature on the subject. Its key components are numbered below:

A cultural model is a relatively coherent configuration of (i) conceptual content that pertains to (ii) a phenomenon, object, person(s), or notion, and that encapsulates an aspect of (iii) worldview professed by (iv) a cultural group or a community.

It is against this backdrop that an attempt will be made here to reconstruct a cultural model of the immigrant as the Other in selected examples of English-language media discourse. In contrast to the notion of "discourses" (Chovanec and Molek-Kozakowska 2017) referenced above, it is more appropriate here to talk about "discourse" because of a specific selection of the data for analysis. This limited corpus consists of six articles that come from five press titles and one radio website, from five major English-speaking regions (Great Britain, the USA, Canada, Australia, and New Zealand), all of them representing democraticliberal, perhaps leftist media rhetoric. If the selection of the material seems biased, this in fact is premeditated and purposeful: no claims are made as to the statistical significance of the 
findings or the representativeness of the samples for the media in those countries. Rather, the study is an exercise in cultural model reconstruction: its goal is to propose a specific variant of the cultural model of the immigrant as the Other, so as to be able, upon collecting and analysing a larger and more diverse corpus, to locate it within the more complex configuration of differential cultural models. In that sense, the present study is part of a larger endeavour ${ }^{3}$.

The body of data that come from geographically diverse backgrounds but connected through the common theme of the English language allows us to reconstruct a cultural model of the immigrant in the sense of James Underhill's (2011) cultural mindset, which that author defines in terms of worldview. It is a worldview that "must take root within a given linguistic worldview but which can migrate between language systems (as the spread of Catholicism, Protestantism, Buddhism and communism clearly demonstrates)" (Underhill 2011: 6-7) . Thus, Underhill views the cultural mindset as ideological in that although it originates in notions that exist in a specific language (Humboldt's Weltansicht), it gravitates towards a cross-linguistically functioning ideological worldview (Humboldt's Weltanschauung). In my proposal here, Underhill's cultural mindset assumes a somewhat different shape: the media samples under analysis all come from English-speaking countries, distant geographically and relatively distinct culturally, but united through a common tongue. Thus, the worldview here "migrates" between those areas and the different varieties of their shared language.

\section{Analysis}

Table 1 lists the sources of the language data. In what follows, the individual articles will be identified through their acronyms provided in the Table's second column.

Table 1. Sources of data for analysis

\begin{tabular}{|l|l|l|}
\hline Article title, author, date & Magazine or website & Country \\
\hline “What our fear of refugees says about & The New Statesman (NS) & UK \\
Europe”, Slavoj Žižek, 29 Feb 2016 & & \\
\hline “Trump disparages ‘dumb' deal with & National Public Radio website & US \\
Australia on refugees", Bill Chappell, Feb 2, & (NPR) & \\
2017 & & US \\
\hline "Untangling the immigration debate”, Kelefa & The New Yorker (NY) & \\
\hline Sanneh, 31 Oct, 2016 & & \\
\hline
\end{tabular}




\begin{tabular}{|l|l|l|}
\hline $\begin{array}{l}\text { “Anti-Muslim hatred has no place in my } \\
\text { Canada", Margaret Wente, Apr 3, 2017 }\end{array}$ & The Globe and Mail (G\&M) & Canada \\
\hline $\begin{array}{l}\text { "Australia's Shipwrecked Refugee Policy", } \\
\text { Robert Manne, March 2013 }\end{array}$ & The Monthly (M) & Australia \\
\hline $\begin{array}{l}\text { "There's no need to fear migrants", Alex } \\
\text { John-Henry, The Reader Report, 5 Feb 2016 }\end{array}$ & Stuff (S) & $\begin{array}{l}\text { New } \\
\text { Zealand }\end{array}$ \\
\hline
\end{tabular}

The material excerpted from the articles has been arranged into three macro-foci, content areas with regard to the focus of specific linguistic samples: (i) the OBJECT macro-focus, i.e. the actual immigrants, the Others; (ii) the speaking or conceptualising SUBJECT macro-focus, i.e. the speaker/writer/conceptualiser; and (iii) the ambivalent OBJECT-cum-SUBJECT macro-focus.

This tripartite kind of focus needs a brief justification. It aligns with the subject-oriented approach to meaning that is clearly recognisable in at least three interrelated (although also largely distinct) approaches: cognitive linguistics, cognitive ethnolinguistics, and Anna Wierzbicka's Natural Semantic Metalanguage. The present approach comes closest to the first of those, although it also draws (indirect) support from the other two. In cognitive linguistics, for example in Ronald Langacker's $(1987,2008)$ Cognitive Grammar, language units are treated not as containers for meaning but as access nodes to conceptual networks. In cognitive ethnolinguistics, in turn, one of the descriptive instruments is the cognitive definition (Bartmiński 2009, ch. 6; 2013), which aims to account for the nature of the mental object associated with a given element or portion of experience. Finally, Wierzbicka (1996; Goddard and Wierzbicka 2014) constructs semantic explications in order to answer the question "What do people think when they say X?". All these approaches are concerned with what the study of language can tell us about the conceptualisations produced by its speakers.

An area of special interest, a domain where the most semantically and conceptually interesting processes take place, is the nexus of OBJECT-oriented and SUBJECT-oriented inquiry (the OBJECT-SUBJECT macro-focus). However, each of the three broad macro-focus areas is further divided into more specific foci, which are here called micro-foci. Five such micro-foci have been identified for the OBJECT macro-focus, three for the SUBJECT macrofocus, and four for the ambivalent OBJECT-OBJECT macro-focus. They are all listed and discussed below. 


\subsection{Macro-focus on OBJECT}

With its five micro-foci, the OBJECT macro-focus is the most diversified of the three, at least with regard to the body of data analysed. The five micro-foci are be listed below, with examples and the necessary commentary to each.

\subsubsection{Micro-focus: CONTRASTING ATTITUDES}

The discussion on the Other is framed here in between opposing or contrasting attitudes to immigrants, represented by different socio-political factions:

- The vindictive behaviour of the Hawke and Keating governments [in Australia, 19831996, A.G.] regarding the Cambodians contrasts starkly with the generosity the Fraser government [1975-1983, A.G.] showed to the Vietnamese. (M)

- Our interest is to integrate new Canadians, not segregate them. (G\&M)

\subsubsection{Micro-focus: REACTION TO ANTAGONISTIC DISCOURSE}

In several contexts, the authors of the articles analysed here express their concern with and a need to counter what they consider a hurtful approach, detrimental to public discourse:

- There are two dimensions here which should be kept apart. One is the atmosphere of fear, of the struggle against the Islamization of Europe, which has its own obvious absurdities. Refugees who flee terror are equated with the terrorists they are escaping from. (NS)

- But we can discourage the fear-mongers and the hate-mongers from poisoning our public discourse. (G\&M)

These allegations are also portrayed as a sentiment wrongly accepted as factual:

- For much of this year ... Donald Trump ... captured the Republican Presidential nomination by giving voice to a sentiment that many Republican voters evidently believe ...: that immigration is destroying America. (NY)

- Because of enthusiasm for the dismantling of the White Australia policy, both the government and the Whitlam and Hayden Opposition [in the 1970s, A.G.] were careful not to stir underlying racist sentiment... (M) 


\subsubsection{Micro-focus: INSISTENCE ON REGARD FOR AND INFORMED INTERPRETATION OF FACTS}

This micro-focus is related to the previous one in that commonly accepted views are contrasted with facts:

- with reference to President Obama's consent to accept refugees in an agreement with Australia, Trump's tweet incorrectly labels refugees 'illegal immigrants' and cites 'thousands' of people instead of 1,250 (NPR)

- there is a need for an informed analysis of immigration's effect on American economy: Plyler v. Doe was a 1981 Supreme Court case [in the US, A.G.] that gave unauthorized immigrant children the right to enroll in public school. Justice William Brennan wrote [...], "There is no evidence in the record suggesting that illegal entrants impose any significant burden on the State's economy." (NY)

- with reference to the so-called the 1980 Mariel boatlift (over 100,000 Cubans arriving in Florida), David Card, a labor economist known for his research on the minimum wage, [...] found no evidence that the influx had lowered wages in Miami. (NY)

Facts (especially with regard to the economy) must not only be known but also interpreted in a manner that is informed and deprived of prejudice:

- New Zealand's population is growing rapidly, at an astonishing rate, but the rate is in fact comparable to that of Australia (S)

- Joseph Carens, an American political scientist [...] assumes that immigrants, when not thwarted by cruel policies, will generally make good use of the economic opportunities available; he suggests that the costs of immigration will be small, or nonexistent. Similarly, Hillary Clinton, who once declared herself "adamantly against illegal immigrants," is now much more likely to enumerate the ways in which immigrants, whether authorized or not, enrich the nation's economy... (NY)

- We need immigrants, especially working-age immigrants. They have a positive impact on job market, retirement payments, etc. (S)

Otherwise, the immigrant Others are easily targeted as responsible for what no single social or political actor can control (cf. in this context Lirola (2017) on the criminalisation of immigrants):

- problems which are immanent to today's global capitalism are projected onto an external intruder (NS) 


\subsubsection{Micro-focus: INCOMPETENT RESPONSE TO THE PROBLEM}

One of the causes of this status quo is what are judged to be inadequate policies of governments and powers-that-be with regard to the issue of immigration, which in consequence has contributed to the reserved or hostile attitude to otherness:

- Australia's asylum seeker politics is toxic and its asylum seekers policy is in shambles (M)

- $\quad$ ooor response of New Zealand's authorities to the immigration problem (S)

\subsubsection{Micro-focus: CULTURAL ASPECT}

A change of this attitude is portrayed as welcome, which can be achieved by realising that the host country benefits from the diversity of the otherness on the cultural level:

- greater richness, depth of culture, variety of perspectives and experiences, vibrancy, colour, food, music, art (S)

\subsection{Macro-focus on SUBJECT}

The macro-focus on the SUBJECT involves three micro-foci: the focus must actually be shifted from OBJECT (rather obvious) to SUBJECT (less obvious), the SUBJECT focus can be individual or collective, and the focus may be linked to an appeal to the compassion and sympathy that is to be expected of humans.

\subsubsection{Micro-focus: REFOCUSING FROM OBJECT TO SUBJECT}

In any discourse, the natural focus is the OBJECT of that discourse, so that a shift to the SUBJECT requires extra justification:

- Descartes [...] noted that when he was young foreign people's manners and beliefs seemed to him ridiculous and eccentric, until he asked himself whether our own manners and beliefs may appear the same to them. [...] We should learn to experience ourselves as eccentric, to see our customs in all their weirdness and arbitrariness. (NS)

The author here makes an analogy between Descartes's experience and our experience of immigrants. This may be unintentional and subconscious:

- anti-refugee rhetoric is an ideological pathology and tells more about us, Europeans than about immigrants (NS) 
but a conscious shift of viewpoint is also recommended for a more informed perspective:

- we should not recognise ourselves in strangers, but ... recognise a stranger in ourselves (NS)

\subsubsection{Micro-focus: GROUP OR INDIVIDUAL SUBJECT}

An interplay of individualistic or collective construals of the conceptualising SUBJECT is illustrated with the excerpt below. The article is concerned with the place and role of Islam and Muslim lifestyle in Canada, especially in Canadian schools. The author supports what she calls "religious accommodation" and notes:

- Religious accommodation is always a touchy subject, but the opposition to this plan is simply wrong. There is no place for it in my Canada. [...] That's supposed to be the Canadian way, and I don't want to lose it. (G\&M)

The author projects an egocentric perspective on how she navigates through social reality ( $m y$ Canada). In the same sentence, however, she zooms out of her own personal frame and assumes a collective, more objectified perspective (the Canadian way). This may illustrate two processes: either (i) extrapolation from the individual onto the group subject, or reversely (ii) inheriting the individual attitude from the collective one and accepting it as one's own. Bradd Shore calls these processes objectification and subjectification, respectively (Shore 2012: $112)^{5}$. The collective frame clearly dominates in the third micro-focus in this macro category, below.

\subsubsection{Micro-focus: APPEAL TO "THE HUMAN" WITHIN US}

In focusing on and advocating the humaneness of decisions and actions, the authors project a communal, collective, or group perspective (the unmistakably positive message of these excerpts contrasts with what Taylor (2017) has identified as use of the notion of COMMUNITY for othering):

- It seems to be an instinctive aspect of human nature to distrust outsiders and anyone who doesn't look like us. [...] But we have moved on from our cave dwelling past, we are quite capable of rising above our evolutionary dispositions. (S)

- liberal democracy is able to accommodate different ethnicities, cultures, political views and religions $(\mathrm{S})$

- [reference to President Obama], we must not let ourselves be deficient in common humanity (NY) 


\subsection{Macro-focus: ambivalent OBJECT-SUBJECT}

As any strict division, that into OBJECT and SUBJECT proposed above tends to break down in more complex cases, sufficiently so to warrant a recognition of a distinct, albeit an ambivalent OBJECT-SUBJECT focus. It is suggested that it be further divided into four micro-foci.

\subsubsection{Micro-focus: TERMINOLOGY}

The terminology listed in point 1 , some of which comes from other authors, quoted by the media, is neutral, politically correct, nondivisive, often legal - it would not be an exaggeration to call it courteous, occasionally verging on poetic (cf. vulnerable stranger in our midst):

- $\quad$ immigrants, migrants, refugees, irregular migrants (NY), newcomers (G\&M), entrants (NY), asylum seekers (M), non-repatriated refugees $(\mathrm{M})$, vulnerable stranger in our midst $(\mathrm{M})$, new arrivals $(\mathrm{S})$, new Canadians $(\mathrm{G} \& \mathrm{M})$, people in other countries who would like to come to this one $(\mathrm{NY})$

\subsubsection{Micro-focus: HOST-IMMIGRANT POSITIVE TENSION}

The existence of tensions between the hosts and the immigrants is not denied but is here portrayed as a potentially productive challenge:

- [David Miller, a political philosopher at Oxford,] views the tension in terms of a double vulnerability: by applying for asylum, a refugee "makes herself vulnerable" to a state, while imposing on the state a "duty of care." (NY)

- [Joseph Carens, an American political scientist,] thinks we do have a special duty to immigrants; namely, a duty to make them feel like members of society (NY)

\subsubsection{Micro-focus: VIEWPOINT OF THE OTHER}

This kind of attitude admits of the viewpoint of the immigrant Other:

- [W]elcome to the country all you visitors and new New Zealanders. [...] I hope you will embrace the freedoms that this little slice of paradise has to offer. (S)

In his direct address to the incomers, the author here nevertheless shifts his perspective to that of the addressee within a single sentence: New Zealand is considered a slice of paradise from the perspective of the vulnerable immigrants, rather than from the perspective of those who take it for granted. 


\subsubsection{Micro-focus: VALUES VS. PRACTICES}

What makes this possible are the values cherished by the inhabitants of the host country (this also links to the 2.2.3. micro-focus above on the humanitarian aspect and the communal dimension of our decisions):

- rejection of immigrants is abandonment of "liberal principles" because morality requires states to act in ways that may not be to their advantage (NY)

In New Zealand, it is dubious whether there exists a uniform set of values, as it has seen debates "on a wide range of issues such as euthanasia, marriage equality, politics and religion" (S). Therefore,

- [t]he beauty of a liberal democracy is that it can accommodate different ethnicities, cultures, political views and religions. The only common value [...] is a respect for the principles of liberalism, such as freedom of speech, freedom of religion (and nonreligion), rule of law, civil rights, democracy and separation of religion from the state.

A liberal democracy welcomes different perspectives and beliefs and accepts disagreement and criticism, as long as the fundamental rights of others are respected.

If these appear abstract, the author of the NS article ${ }^{6}$ suggests that what can help us handle the issues of the immigrant Other is a consideration of the way of life. This is where the SUBJECT and OBJECT, the immigrant Other, both come into the equation: the way of life is understood not as abstract values but everyday practices:

- how we eat and drink, sing, make love, relate to authorities (NS)

\section{Towards a synthesis and a conclusion}

An attempt is made above to reconstruct, not a cultural model of the immigrant Other in its totality, but of its variant or profile (a sub-model) as it transpires through liberal-democratic English media discourse. Because, furthermore, the analysis is based on a limited selection of sources even within that sub-model, this is an analytical exercise with no claims to comprehensiveness ${ }^{7}$. But from this point on, one could and should extend the analysis onto other genres and other ideologies (in the sense of worldviews). Crucially, it is hoped that the notion of a cultural (or cognitive-cultural) model will help account for what happens when we 
want to satisfy our need to "reconcile [our ...] cognitive capacities for autonomous awareness with [...] social and cultural interdependence" (Shore 2012: 109).

The present study has also been inspired by, although it does not strictly follow, Underhill's $(2009,2011)$ notion of cultural mindset. It aligns with Underhill's framework in that a cultural model qua cultural mindset is an ideological parameter of worldview. Where it departs from Underhill is that rather than bridging languages, a cultural mindset here bridges geographical and cultural areas within a single language. This is best viewed, however, as an adaptation, not a distortion of Underhill's main line of argumentation.

Finally, as an additional theoretical advancement, the notion of cultural model could be developed more systematically not only in cognitive anthropology (which it has been) but also in cognitively oriented cultural linguistics - specifically the Cultural Linguistics [sic!] enterprise as proposed by Farzad Sharifian (most recently, 2017b) and pursued by a number of scholars to various "degrees of separation" in Sharifian (2017a). If the place of cultural models can be more precisely established within the larger set of constructs that embraces cultural categories, cultural schemas, and cultural metaphors, the framework of Cultural Linguistics would gain an extra level of coherence and reliability. Therefore, should the present attempt to correlate the notion of cultural model with that of Underhill's cultural mindset be deemed successful, each of the two frameworks can contribute to the development of the other in concerted fashion.

\section{Notes}

\footnotetext{
${ }^{1}$ A similar, though of course not identical understanding of the Other, is proposed in post-colonial context by e.g. Costa dos Santos Benedito: "In general terms, the Other, in the sense post-colonial critics [...] use it, that is, the non-Western, was (and still is in some contexts) associated with the primitive, non-civilized, barbarian, connected to a subculture and always contrasted with Western, white and civilized world" (2017: 179).

2 The following names can be mentioned in this context: Naomi Quinn, Dorothy Holland, Claudia Strauss, Roy D’Andrade, Edwin Hutchins, David Kronenfeld, Giovanni Bennardo, Victor C. De Munck, or Farzad Sharifian.

${ }^{3}$ For a study of right-wing discourse in UK media cf. e.g. Fielder and Catalano (2017).

${ }^{4}$ For more details on the model cf. also Underhill (2009); for an application cf. Wyrwa (2017).

${ }^{5}$ For a compelling example of blending the individual and collective frames cf. Everett (2008: 67) on the Pirahã, who can switch from one to the other within the same speech event without producing inconsistency or conceptual discord. For an extended analysis of egocentric vs. allocentric perspectival frames and cultural models in English press discourse, cf. Głaz (forthcoming).

${ }^{6}$ The author is Slavoj Žižek, and so a non-native speaker (and writer) of English. On the other hand, any article published in The New Statesman is most certainly subjected to meticulous editorial process, including those coming from acclaimed (and controversial) authors such as this one. Also, Žižek has functioned in Englishlanguage public discourse for a long time. In short, it is doubtful if any specifically non-native features of style can be identified in the article quoted here.

${ }^{7}$ In fact, a fully comprehensive picture might not be possible to achieve, given not only the open-ended nature of linguistic semantics but the richness of the socio-political context of (im)migration. An in-depth study by Thomas Nail (2015) gives one a taste of that richness.
} 


\section{References}

Bartmiński, Jerzy (2009) Aspects of Cognitive Ethnolinguistics. London and Oakville, CT: Equinox.

Bartmiński, Jerzy (2013) “The Cognitive Definition as a Text of Culture.” [In:] Adam Głaz, David S. Danaher, Przemysław Łozowski (eds.), The Linguistic Worldview. Ethnolinguistics, Cognition, and Culture. London: Versita, 161-180. [open access:]

Bennardo, Giovanni, Victor C. de Munck (2014) Cultural Models: Genesis, Methods, and Experiences. New York: Oxford University Press.

Chovanec, Jan, Katarzyna Molek-Kozakowska (eds.) (2017) Representing the Other in European Media Discourses. Amsterdam/Philadelphia: John Bejamins.

Costa dos Santos Benedito, Fernanda (2017) “The Representation(s) of 'The Other' in Passage to India by David Lean.” Journal of Literature and Art Studies, 7 (2); 179185. doi: 10.17265/2159-5836/2017.02.005

D’Andrade, Roy G. (1989) “Cultural Cognition.” [In:] Michael I. Posner (ed.), Foundations of Cognitive Science. Cambridge, Mass.: MIT Press; 795-830.

Everett, Daniel L. (2008) Don't Sleep, There are Snakes. Life and Language in the Amazonian Jungle. New York: Vintage Departures.

Fielder, Grace E., Theresa Catalano (2017) “Othering Others.” [In:] Jan Chovanec and Katarzyna Molek-Kozakowska (eds.), Representing the Other in European Media Discourses. Amsterdam/Philadelphia: John Benjamins; 207-234.

Głaz, Adam (forthcoming) "Analogy in Action: From Space-time to Differential Cultural Models.” [In:] Barbara Lewandowska-Tomaszczyk, Marcin Grygiel (eds.), Contrast and Analogy in Language: Perspectives from Cognitive Linguistics. Amsterdam/Philadelphia: John Benjamins.

Goddard, Cliff, Anna Wierzbicka (2014) Words and Meanings: Lexical Semantics Across Domains, Languages, and Cultures. Oxford: Oxford University Press.

Hegel, Georg Wilhelm Friedrich (1807) Phänomenologie des Geistes. Bamberg und Würzburg: Joseph Anton Goebhardt.

Husserl, Edmund (1931) Méditations cartésiennes: Introduction à la phénoménologie. Trans. Gabrielle Peiffer and Emmanuel Lévinas. Paris: Armand Collin. 
Hutchins, Edwin (1995) Cognition in the Wild. Cambridge, Mass.: The MIT Press.

Kapuściński, Ryszard (2009) The Other. Trans. Antonia Lloyd-Jones. London and New York: Verso.

Kristiansen, Gitte, René Dirven (2008) “Introduction. Cognitive Sociolinguisitcs: Rationale, Methods and Scope." [In:] Gitte Kristiansen, René Dirven (eds.), Cognitive Sociolinguistics: Language Variation, Cultural Models, Social Systems. Berlin and New York: Mouton de Gruyter; 1-17.

Kronenfeld, David (2018) Culture as a System: How We Know the Meaning and Significance of What We Do and Say. London: Routledge.

Lacan, Jacques (1997/1981) The Seminar. Book III. The Psychoses, 1955-1956. Trans. Russell Grigg [Le Seminaire, Livre III, Les Psychoses. Paris: Éditions du Seuil]. New York: W. W. Norton \& Company.

Langacker, Ronald W. (1987) Foundations of Cognitive Grammar. Vol. 1. Theoretical Prerequisites. Stanford, CA: Stanford University Press.

Langacker, Ronald W. (2008) Cognitive Grammar: A Basic Introduction. Oxford: Oxford University Press.

Lévinas, Emmanuel (1961) Totalité et Infini: Essai sur l'extériorité. La Haye: Martinus Nijhoff.

Lévinas, Emmanuel (1974) Autrement qu'être ou au-delà de l'essence. La Haye: Martinus Nijhoff.

Lirola, María Martínez (2017) "Discursive Legitimization of Criminalization and Victimization of Sub-Saharan Immigrants in Spanish El País and ABC Newspapers.” [In:] Jan Chovanec and Katarzyna Molek-Kozakowska (eds.), Representing the Other in European Media Discourses. Amsterdam/Philadelphia: John Benjamins; 135-154.

Nail, Thomas (2015) The Figure of the Migrant. Stanford, CA: Stanford University Press.

Sartre, Jean-Paul (1943) L'Être et le néant: Essai d'ontologie phénoménologique. Paris: Gallimard.

Sharifian, Farzad (ed.) (2017b) Advances in Cultural Linguistics. Singapore: Springer.

Sharifian, Farzad (2017a) Cultural Linguistics. Amsterdam/Philadelphia: John Benjamins.

Shore, Brad (2012) "Egocentric and Allocentric Perspectives in Cultural Models." [In:] Ron Sun (ed.), Grounding Social Sciences in Cognitive Sciences. Cambridge, MA: MIT Press; 89-123. 
Taylor, Charlotte (2017) “Togetherness or Othering?” [In:] Jan Chovanec and Katarzyna Molek-Kozakowska (eds.), Representing the Other in European Media Discourses. Amsterdam/Philadelphia: John Benjamins; 55-80.

Underhill, James W. (2009) Humboldt, Wordview, and Language. Edinburgh: Edinburgh University Press.

Underhill, James W. (2011) Creating Worldviews: Metaphor, Ideology and Language. Edinburgh: Edinburgh University Press.

Wierzbicka, Anna (1996) Semantics: Primes and Universals. Oxford: Oxford University Press.

Wyrwa, Anna (2017) "Personal World and Valuation in Interlingual Debate." [In :] Joanna Ziobro-Strzępek, Władysław Chłopicki (eds.), Across Borders 6. The West Looks East. Krosno: Państwowa Wyższa Szkoła Zawodowa im Stanisława Pigonia; 59-73. 